\title{
Kajian Antrian Pelayanan Pendaftaran Pasien BPJS di Rumah Sakit
}

\section{Queue Analysis of BPJS Patient Registration Services in Hospital}

\author{
Ade Heryana ${ }^{*}$, Erlina Puspitaloka Mahadewi ${ }^{1}$, Iyan Ayuba ${ }^{2}$ \\ ${ }^{1}$ Program Studi Kesehatan Masyarakat, Universitas Esa Unggul \\ *email : heryana@esaunggul.ac.id \\ 2Program Studi Manajemen, Fakultas Ekonomi, Universitas Gorontalo
}

\begin{abstract}
The enhancement of patient's visit to hospital led to the increasing of length of queue particularly at registration division. This condition made the long duration of waiting time for patients. Hospital's management should manage the patients queue especially for the period of bottle neck condition. This operation research reviewed the patients queue at existing outpatient registration service system and proposed the optimal system based on queuing theory and trade-off analysis of cost of service and cost of waiting. Cross-sectional data applied to collect the patient's arrival rate, service time for every server, waiting cost, and queue related behavior. Result of this study suggested that existing system was non-steady state system and not optimum based on trade-off analysis. Patients who came at least 08.00 am should serve with 2 servers of queue number service, and 6 servers of outpatient registration. Whereas patients who came after 08.00 am should serve with 1 servers of queue number service, and 2 servers of outpatient registration. This study recommended the range of patient's arrival and service rate that the describe viability of optimum system. This study suggested hospital's management should be focus on manage the patient arrival at early morning with applied the suitable queue management technology to controlling the registration waiting line.
\end{abstract}

Keywords; queue analysis, hospital, registration service, outpatient service

\begin{abstract}
Abstrak
Peningkatan kunjungan pasien ke rumah sakit menyebabkan antrian pasien khususnya pada pelayanan rawat jalan bertambah. Kondisi ini menyebabkan waktu tunggu pelayanan menjadi lama. Manajemen rumah sakit sebaiknya mengelola antrian pasien terutama pada pelayanan yang mengalami hambatan (bottle neck). Penelitian operasional ini bertujuan mengkaji antrian pasien pada sistem pelayanan pendaftaran rawat jalan dan merekomendasikan sistem yang optimal berdasarkan analisis dengan teori antrian dan trade-off antara biaya pelayanan dengan biaya menunggu per pasien. Pengumpulan data secara potong lintang untuk mengetahui tingkat kedatangan pasien, tingkat pelayanan tiap loket pelayanan, dan perilaku pasien saat mengantri. Hasil penelitian menunjukkan sistem pelayanan yang ada saat ini dalam kondisi tidak steady state dan tidak optimum berdasarkan analisis trade-off. Direkomendasikan untuk mengoperasikan 2 loket pengambilan nomor antrian dan 6 loket pendaftaran rawat jalan bagi pasien yang datang sebelum jam 08.00, serta mengoperasikan 1 loket pengambilan nomor antrian dan 2 loket pendaftaran rawat jalan bagi pasien yang datang setelah jam 08.00. Pada studi ini peneliti juga merekomendasikan rentang tingkat kedatangan pasien dan tingkat pelayanan yang dapat diterapkan untuk sistem yang optimal. Disarankan agar
\end{abstract}


manajemen rumah sakit memfokuskan pengelolaan kedatangan pasien dan antrian pasien pada pagi hari, dengan menerapkan teknologi pengelolaan atrian yang sesuai.

Kata kunci; analisis antrian, layanan pendaftaran, layanan rawat jalan, rumah sakit

\section{PENDAHULUAN}

Perkembangan jumlah kepesertaan Jaminan Kesehatan Nasional (JKN) yang semakin meningkat tiap tahun disertai dengan kebijakan yang mewajibkan pelayanan kesehatan terutama rumah sakit pemerintah melayani pemeriksaan pasien BPJS Kesehatan, menyebabkan antrian pendaftaran pasien semakin panjang dan perlu penanganan yang baik. Hasil pengamatan awal oleh peneliti menunjukkan antrian pelayanan pendaftaran pasien BPJS Kesehatan RSU Kabupaten Tangerang terutama pada pagi hari sangat padat, bahkan beberapa pasien sudah mengantri sejak dini hari. Pihak manajemen rumah sakit sudah berupaya mengatasi hal ini dengan menambah petugas perbantuan di loket pengambilan nomor dan pendaftaran rawat jalan, namun kepadatan pengunjung tetap terjadi. Dengan tingkat kedatangan yang lebih tinggi dari tingkat pelayanan yang ada saat ini menunjukkan kondisi yang tidak steady state pada sistem antrian. Bila tidak ada pembenahan dalam pengelolaan antrian, akan menyebabkan kondisi yang sulit terkendali dan menyebabkan rendahnya mutu pelayanan.

Berbagai penelitian tentang optimalisasi sistem antrian dengan queuing theory di Indonesia jarang ditemui. Penelitian yang mengoptimalkan biaya pelayanan dan biaya menunggu telah dilakukan oleh (Lisdawati dkk, 2015) di RS Marzoeki Mahdi kota Bogor, serta studi (Heryana, 2001) yang meneliti optimalisasi petugas pelayanan resep di sebuah apotik swasta di Jakarta. Penelitian ini bermaksud memberikan gambaran tentang parameter antrian berdasarkan formula teori antrian (queueing theory) dan mengusulkan sistem antrian yang optimal berdasarkan analisis trade-off biaya pelayanan dan biaya menunggu pasien.

\section{METODE}

Jenis penelitian ini merupakan penelitian observasional kuantitatif, dengan desain riset operasional dan survey, pengumpulan data secara cross-sectional. Populasi adalah seluruh pasien BPJS Kesehatan yang berkunjung atau melakukan pendaftaran di RSUD Kabupaten Tangerang pada periode bulan Januari-Maret 2018. Pembambilan sampel dengan metode purposive sampling yaitu menurut tujuan peneliti dimana responden diambil adalah seluruh pengunjung pada hari pelayanan antara Senin s/d Kamis. Jumlah minimal sampel yang diambil adalah 5\% dari rata-rata kunjungan pasien per hari yaitu $5 \%$ x $410=21$ atau 84 pasien selama 4 hari kerja. Relisasinya untuk analisis sistem diperoleh sampel sebanyak 100 untuk tiap loket pelayanan, dan untuk studi persepsi pasien terkumpul sampel sebanyak 94 responden. Inklusi sampel adalah pasien yang bersedia dan sanggup dilakukan wawancara. Kerangka penelitian dan variable penelitian disajikan pada gambar 1 berikut. 


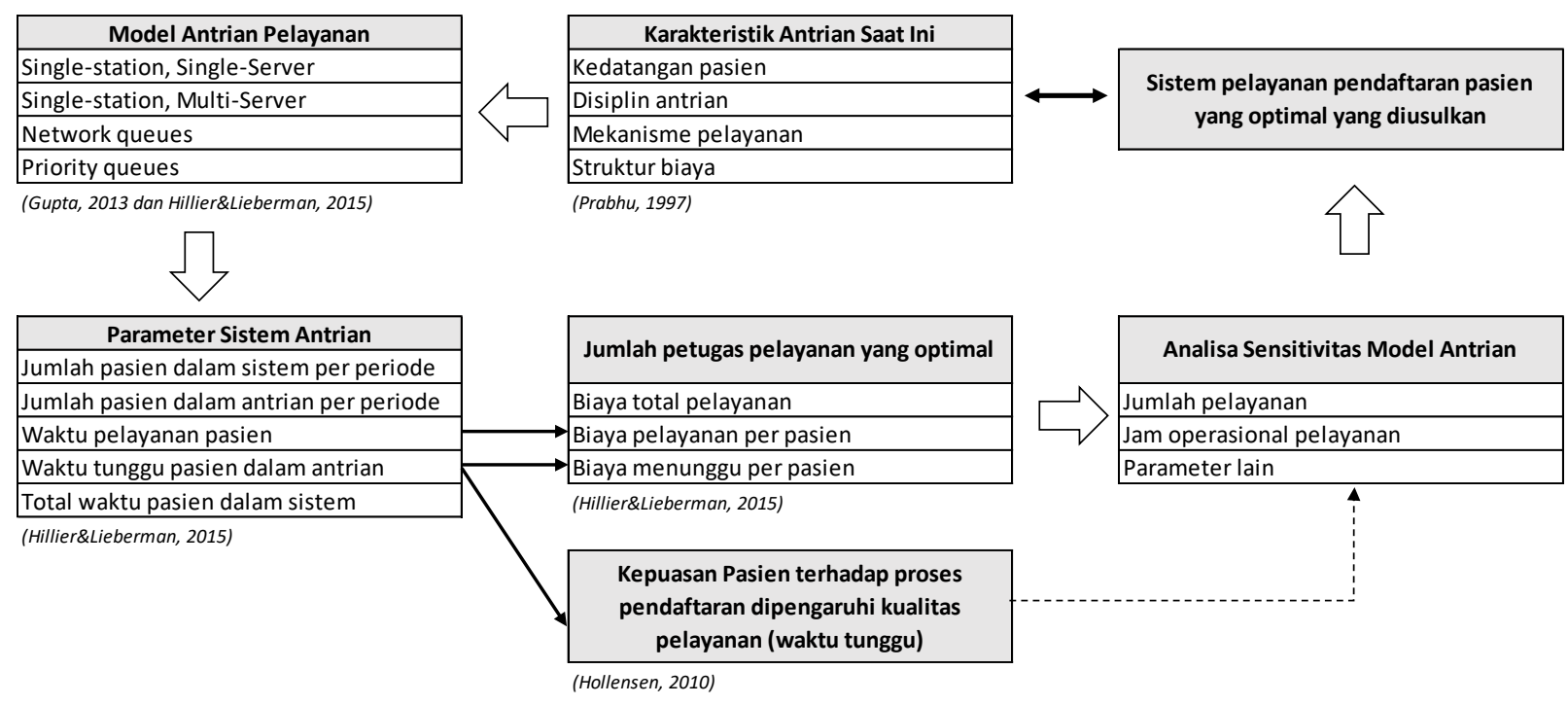

Gambar 1. Kerangka Penelitian. Sumber: Gupta(2013), Hillier \& Lieberman (2015), Prabhu(1997), Hollensen(2010)

\section{HASIL DAN PEMBAHASAN}

\section{Alur Pelayanan Pendaftaran Pasien}

Pelayanan pendaftaran pasien BPJS terdiri dari dua yaitu (1) proses pengambilan nomor antrian; dan (2) proses pendaftaran rawat jalan. Proses pengambilan nomor antrian dilayani oleh satu loket yang terdiri dari 1 petugas tetap, 1 petugas perbantuan khusus pagi, dan 1 security yang membantu penyerahan nomor. Sedangkan pendaftaran yang khusus melayani pasien BPJS Kesehatan terdiri dari 3 loket. Dari 3 loket tersebut, 1 loket dioperasikan oleh supervisor, sehingga kadang loket ini tutup karena melakukan pekerjaan diluar pendaftaran. Alur pelayanan disajikan pada Gambar 2. Disiplin pelayanan dilakukan secara first-come first-served (FCFS) di tiap loket.

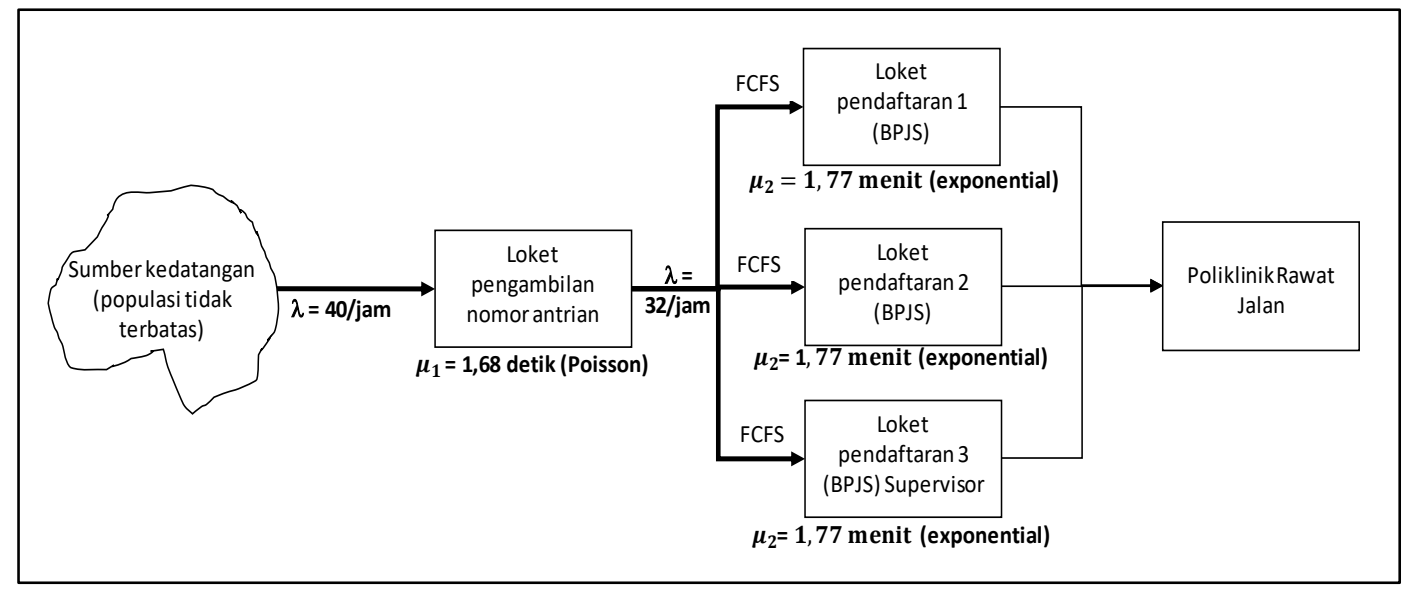

Gambar 2.Model Antrian Sistem Pelayanan Saat ini.

Waktu pelayanan di loket pengambilan nomor rata-rata 16,8 detik (CI 95\% = 14,0 - 19,6) per pasien, dengan range antara 3 - 78 detik, atau dengan tingkat pelayanan 214 pasien per jam. Waktu pelayanan di loket pendaftaran rawat jalan rata-rata 1,77 menit $(C I 95 \%=1,650-1,879)$ per pasien atau 34 pasien per jam (Tabel 1).

Proses pengambilan nomor antrian dilayani oleh 1 loket yang terdiri dari 3 petugas antara lain petugas yang sepanjang hari melayani, petugas pemberi 
nomor (dibantu security) dan petugas perbantuan yang datang pada pagi hari saja. Sedangkan pada proses pendaftaran pasien BPJS Kesehatan dilayani oleh 3 loket, yakni 2 loket khusus melayani pendaftaran BPJS, dan 1 loket melayani BPJS Kesehatan dan merangkap supervisor. Disiplin pelayanan di seluruh loket BPJS Kesehatan menggunakan prinsip First-Come First-Served. Mekanisme pelayanan pada proses pengambilan nomor antrian adalah single-server, sedangkan pada proses pendaftaran rawat jalan dengan multi-server parallel artinya pasien dapat masuk ke loket manapun tergantung pemanggilan oleh mesin antri.

Tabel 1. Distribusi Frekuensi Waktu Pelayanan di Loket Pengambilan Nomor Antrian

\begin{tabular}{lcc}
\hline Statistik & $\begin{array}{c}\text { Waktu Pelayanan } \\
\text { Pengambilan nomor } \\
\text { antrian }\end{array}$ & $\begin{array}{c}\text { Waktu Pelayanan } \\
\text { Pendaftaran Rawat Jalan }\end{array}$ \\
\hline Mean & 16,8 detik & 1,77 menit \\
CI 95\% & $13,996-19,604$ & $1,650-1,879$ \\
SD & 14,13 detik & 0,06 menit \\
SE & 1,41 detik & 1,09 menit \\
Range & $3-78$ detik & $1-5$ menit \\
P-value & 0,0000 & 0,0000 \\
Distribusi & Poisson & Poisson \\
\hline
\end{tabular}

Rata-rata waktu pelayanan proses pengambilan nomor antrian adalah 16,8 detik $(\mathrm{CI95} \%=14,0-19,6)$ per pasien. Secara umum pelayanan berlangsung cepat. Namun saat observasi di lapangan didapatkan kendala yang sebagian besar disebabkan oleh peserta BPJS Kesehatan yang kurang memahami sistem rujukan JKN. Kondisi ini menyebabkan petugas harus mengedukasi pasien sambil memberikan nomor antrian. Studi antrian pelayanan pendaftaran rawat jalan di RS Fatmawati menunjukkan hal yang hampir sama. Studi deskriptif ini menggambarkan bahwa masalah antrian saat peengambilan nomor disebabkan yang melayani adalah petugas keamanan yang kadang tidak ada di tempat serta ketidakdisiplinan pasien dalam mengantri (Septiani dkk, 2017). Hal ini juga sejalan dengan penelitian di RSUD Blambangan yang menunjukkan penyebab waktu tunggu lama di layanan farmasi rawat jalan adalah proses screening resep yang lama karena hanya satu petugas saja (Purwanto dkk, 2015).

Rata-rata waktu pelayanan pada proses pendaftaran rawat jalan adalah 1,77 menit $(\mathrm{CI} 95 \%=1,650-1,897)$ per pasien. Adapun waktu pelayanan dihitung sejak pasien dipanggil (dengan mesin antrian) hingga selesai dilayani oleh petugas. Hasil uji kesesuaian distribusi menunjukkan tingkat kedatangan berdistribusi eksponensial negatif, yakni data waktu pelayanan menumpuk di area yang tidak simetris. Studi antrian di RS Fatmawati menunjukkan tingkat pelayanan pasien adalah 33 pasien per jam atau 1 pasien tiap 2 menit (Septiani dkk, 2017).

\section{Kedatangan Pasien}

Berdasarkan hasil survey, 52\% pasien terbiasa datang sebelum jam 07.30, hanya $7 \%$ yang biasa datang di atas jam 10.00. Domisili pasien sebagian besar $(60,6 \%)$ dari Kota Tangerang. Adapun kebiasaan pasien saat melakukan pendaftaran beragam ada yang diwakilkan, didampingi atau secara mandiri (Tabel 2). 
Tabel 2. Distribusi Frekuensi Perilaku Pasien saat Melakukan Pendaftaran

\begin{tabular}{lcc}
\hline Perilaku Mendaftar & Jumlah & $\%$ \\
\hline Mandiri & 34 & 36,2 \\
Didampingi (ambil nomor) & 15 & 16,0 \\
Diwakilkan (ambil nomor) & 4 & 4,2 \\
Didampingi (ambil nomor \& daftar) & 7 & 7,4 \\
Diwakilkan (ambil nomor \& daftar) & 0 & 0,0 \\
Didampingi \& diwakilkan sampai selesai pelayanan & 34 & 36,2 \\
\hline Total & 94 & 100 \\
\hline
\end{tabular}

Untuk keperluan analisis maka kedatangan pasien terbagi dua yaitu: (1) Pasien yang datang sebelum jam 08.00; dan (2) Pasien yang datang sesudah jam 08.00. Adapun jumlah kedatangan dan rata-rata waktu tunggu disajikan pada Tabel 3. Berdasarkan Tabel 3, waktu tunggu sejak pasien mengambil nomor hingga selesai dilayani di loket pedaftaran adalah 108,6 menit (CI95\%: 100,363 $116,850)$ per pasien. Perilaku pasien saat menunggu pelayanan sebagian besar $(88,3 \%)$ besedia menunggu hingga pelayanan selesai. Sementara $7,5 \%$ pasien meninggalkan antrian jika waktu pelayanan terlalu lama, dan 3,2\% menolak mengantri jika melihat antrian panjang.

Tabel 3. Deskripsi Waktu Tunggu, Jumlah Kedatangan Pasien

\begin{tabular}{lcc}
\hline \multicolumn{1}{c}{ Deskripsi } & Ambil Nomor & Daftar Rawat Jalan \\
\hline Kedatangan pasien/jam & & \\
Pasien datang $\leq 08.00$ & 212 & 169 \\
Pasien datang $>08.00$ & 40 & 32 \\
Waktu tunggu per proses (menit) & 109,7 & 107,9 \\
Waktu tunggu seluruhnya (menit) & $108,6$ menit (CI95\%: $100,363-116,850)$ \\
\hline
\end{tabular}

Tingkat kedatangan pasien yang datang $\leq$ jam 08.00 pada proses pengambilan nomor antrian adalah 212 pasien per jam, hal ini berarti tiap 17 detik terdapat 1 pasien yang datang untuk mengambil nomor antrian. Kondisi ini membutuhkan penanganan yang tepat oleh pihak rumah sakit agar tidak menggangu pelayanan yang lain di sekitar gedung pendaftaran. Adapun pasien yang datang di loket pengambilan antrian adalah campuran antara pasien jaminan dengan umum (bayar sendiri). Berdasarkan laporan kunjungan pasien pada tahun 2015, proporsi pasien yang membayar sendiri adalah 20\%. Maka dapat diasumsikan kedatangan pasien ke loket pendaftaran dikurangi dengan 20\% (pasien umum) yaitu menjadi 169 pasien per jam. Hal ini sejalan dengan penelitian antrian pendafataran rawat jalan RSU Kota Semarang yang menunjukkan kedatangan pasien paling banyak antara jam 06.30 - 07.29, namun dengan tingkat kedatangan yang lebih rendah yaitu 34 pasien per jam (Fuanasari dkk, 2014). Begitu pula penelitian antrian pada pelayanan pasien rawat jalan di RSUD Haji Makassar menunjukkan pada 09.00 - 10.00 kedatangan pasien lebih sibuk dibanding jam 11.00 - 12.00 (Wihdaniah dkk, 2018).

Hasil uji kesesuaian distribusi dengan metode Saphiro-Wilk menunjukkan tingkat kedatangan berdistribusi Poisson. Hal ini berarti secara statistik data kedatangan pasien menumpuk di satu kumpulan data atau menunjukkan kesibukan kedatangan di satu titik waktu yaitu pagi hari setelah layanan dibuka. Kesibukan kedatangan pada sebelum jam 08.00 sesuai dengan hasil survey yakni $72,5 \%$ responden datang ke rumah sakit sebelum jam 07.30. Kondisi ini berbeda dengan layanan pengambilan darah yang distribusi kedatangannya tergantung pada waktu yang ditentukan oleh petugas atau timedependent distribution (Van Brummelen dkk, 2018). 
Sedangkan pada pasien yang datang $>$ jam 08.00 pada proses pengambilan nomor antrian adalah 40 pasien per jam dan proses pendaftaran pasien 32 pasien per jam. Artinya kedatangan pasien di atas jam 08.00 cukup lengang, dan setiap pasien datang dalam interval waktu rata-rata 1,5 menit. Kondisi ini sesuai dengan hasil survey kepada pasien yakni hanya $27,5 \%$ pasien yang datang di atas jam 07.30. Studi antrian pasien pendaftaran rawat jalan di RS Fatmawati menunjukkan tingkat kedatangan pasien bervariasi antara 90-94 pasien per jam (Septiani dkk, 2017).

Sebagian besar pasien berdomisili di Kota Tangerang (61\%) dengan sumber kedatangan tidak terbatas. Berdasarkan hasil survey peserta BPJS yang mendaftar bukan hanya berasal dari kota Tangerang, melainkan juga dari kabupaten Tangerang (36\%) dan kabupaten Serang (3\%). Hal ini menunjukkan sumber kedatangan pasien tidak terbatas (infinite sources).

Dalam melakukan pendaftaran, sebanyak $36,2 \%$ pasien melakukan sendiri atau tanpa diwakilkan/didampingi, 16\% didampingi dan 4,3\% diwakilkan orang lain saat pengambilan nomor antrian. Hal ini menunjukkan ada 16 dari 100 pasien yang rentan sehingga harus didampingi oleh keluarga/saudara. Implikasi dari kondisi ini manajemen rumah sakit harus menyediakan kursi tunggu yang cukup karena hanya 36\% saja pasien yang datang sendiri, selebihnya yakni $63 \%$ didampingi oleh keluarga.

Secara umum pelayanan berlangsung cepat, namun karena kedatangan pasien yang tinggi pada pagi hari, terjadi bottle neck di ruang tunggu pendaftaran rawat jalan. Hal ini menyebabkan pasien mengalami waktu tunggu yang lama. Rata-rata waktu tunggu pada seluruh pasien adalah 108,6 menit $(\mathrm{CI} 95 \%=100,4-116,9)$ atau 1 jam 49 menit. Kedatangan yang berdistribusi Poisson menyebabkan pasien yang datang $\leq$ jam 08.00 merasakan waktu yang lama dibanding pasien yang datang > jam 08.00. Waktu ini masih di atas standar yang ditetapkan dalam Standar Pelayanan Minimum (SPM) rumah sakit oleh Kemenkes RI yaitu di bawah 60 menit. Penyebab lamanya pelayanan di loket pendaftaran rawat jalan umumnya adalah konfirmasi kepesertaan BPJS Kesehatan dan gangguan teknis seperti printer yang rusak pada bagian head printer sehingga hasil cetak tidak bagus. Khusus loket 3, petugas pendaftaran merangkap supervisor sehingga harus melayani pekerjaan di luar pendaftaran rutin sehingga loket ini pada beberapa waktu tidak melayani pendaftaran.

Waktu tunggu merupakan atribut pelayanan kesehatan yang harus diawasi dengan ketat, jika pelayanan kesehatan memusatkan perhatian pada pelayanan pasien. Dengan demikian waktu tunggu merupakan ukuran yang penting dari kepuasan pasien. Antrian panjang pasien terjadi ketika pelayanan kesehatan berkerja secara tidak efisien dan memicu ketidakpuasan (Loving et al., 2017).

Berdasarkan survey terhadap perilaku menunggu pasien, diperoleh sebagian $(88,3 \%)$ berperilaku normal yaitu bersedia menunggu hingga selesai dilayani. Sebagian kecil $(7,5 \%)$ atau sekitar $7-8$ dari 100 pasien akan meninggalkan antrian jika pelayanan terlalu lama, sebanyak 3 dari 100 pasien (3\%) menolak melakukan antri jika melihat antrian panjang. Hal ini menunjukkan tingkat ketergantungan pasien BPJS Kesehatan yang tinggi terhadap pelayanan rawat jalan di RSU Kabupaten Tangerang sehingga tetap bersedia mengantri hingga selesai dilayani meskipun harus menunggu dengan waktu yang relatif lama.

\section{Karakteristik, Parameter dan Model Antrian Saat Ini}

Berdasarkan informasi tentang tingkat kedatangan dan pelayanan pasien maka dapat disimpulkan karakteristik sistem berdasarkan notasi Kendall sebagai berikut:

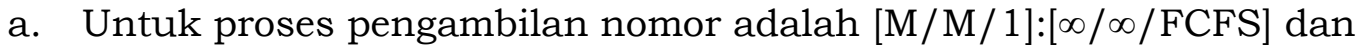

b. Untuk proses pendaftaran rawat jalan adalah $[\mathrm{M} / \mathrm{M} / 3]:[\infty / \infty / \mathrm{FCFS}]$ 
Maka berdasarkan karakteristik tersebut perhitungan parameter menggunakan formula teori antrian single server dan multiserver. Dengan menggunakan rumus teori antrian, diperoleh parameter sistem antrian saat ini yang menunjukkan pelayanan pendaftaran rawat jalan terhadap pasien yang datang sebelum jam 08.00 menunjukkan kondisi yang tidak steady state. Hal ini disebabkan tingkat kedatangan pasien lebih tinggi dibanding tingkat pelayanan pasien per jam. Sehingga kondisi ini tidak dapat dianalisis berdasarkan postulat teori antrian.

Tabel 4. Parameter Sistem Antrian Saat Ini

\begin{tabular}{|c|c|c|}
\hline Parameter & $\begin{array}{l}\text { Pengambilan } \\
\text { Nomor }(c=1)\end{array}$ & $\begin{array}{c}\text { Pendaftaran Rawat } \\
\text { Jalan }(c=3)\end{array}$ \\
\hline Jam Kedatangan Pasien & $\leq$ Jam 08.00 & $\leq$ Jam 08.00 \\
\hline Tingkat kedatangan pasien/jam $(\lambda)$ & 212 pasien/jam & 169 pasien/jam \\
\hline Tingkat pelayanan pasien/jam $(\mu)$ & 214 pasien/jam & 34 pasien/jam \\
\hline Tingkat densitas sistem $(\rho=\lambda / \mu)$ & 0,991 & - \\
\hline Tingkat utilitas sistem $\left(P_{0}\right)$ & $99,065 \%$ & - \\
\hline Jumlah pasien pada antrian $\left(L_{q}\right)$ & 105,009 pasien & - \\
\hline Jumlah pasien pada sistem $(L)$ & 106,000 pasien & - \\
\hline Waktu tunggu pada antrian $\left(W_{q}\right)$ & 0,495 jam & - \\
\hline Waktu tunggu pada sistem $(W)$ & 0,500 jam & - \\
\hline Probabilitas sistem idle atau $P_{(\text {idle })}$ & $0,935 \%$ & \\
\hline Kondisi system & Steady state & Tidak steady state \\
\hline Jam Kedatangan Pasien & >Jam 08.00 & > Jam 08.00 \\
\hline Tingkat kedatangan pasien/jam $(\lambda)$ & 40 pasien/jam & 32 pasien/jam \\
\hline Tingkat pelayanan pasien/jam $(\mu)$ & 214 pasien/jam & 34 pasien/jam \\
\hline Tingkat densitas sistem $(\rho=\lambda / \mu)$ & 0,187 & 0,941 \\
\hline Tingkat utilitas sistem $\left(P_{0}\right)$ & $18,692 \%$ & $31,37 \%$ \\
\hline Jumlah pasien pada antrian $\left(L_{q}\right)$ & 0,043 pasien & 0,036 pasien \\
\hline Jumlah pasien pada sistem $(L)$ & 0,230 pasien & 0,977 pasien \\
\hline Waktu tunggu pada antrian $\left(W_{q}\right)$ & 0,001 jam & 0,001 jam \\
\hline Waktu tunggu pada sistem $(W)$ & 0,006 jam & 0,031 jam \\
\hline Probabilitas sistem idle atau $P_{\text {(idle })}$ & $81,308 \%$ & $68,63 \%$ \\
\hline Kondisi system & Steady state & Steady state \\
\hline
\end{tabular}

Berdasarkan Tabel 4 di atas diperoleh parameter antrian sistem pelayanan saat ini. Terlihat bahwa pendaftaran pasien untuk pasien yang datang $\leq$ jam 08.00 lebih sibuk dibanding pasien yang datang > jam 08.00.

Parameter sistem antrian untuk pelayanan pengambilan nomor (1 loket) untuk pasien yang datang sebelum jam 08.00, memiliki parameter antrian sebagai berikut: (1) Tingkat utilitas sistem antrian adalah 99,065\%, sehingga kemungkinan kecil sekali sistem mengalami idle (kurang dari 1\%); dan (2) Ratarata panjang antrian pada sistem antrian (L) adalah 106 pasien, dengan ratarata waktu menunggu dalam sistem adalah 0,5 jam atau 30 menit per pasien.

Kondisi parameter di atas menunjukkan pelayanan pengambilan nomor antrian untuk pasien yang datang sebelum jam 08.00 terlihat sangat sibuk. Sehingga manajemen rumah sakit perlu melakukan pengelolaan pada pagi hari agar tidak terjadi kecauan dalam antrian. Sementara pada proses pelayanan pelayanan pendaftaran rawat jalan dalam kondisi tidak steady state. Hal ini disebabkan tingkat kedatangan pasien lebih besar dibanding tingkat pelayanan. Kondisi ini tidak dapat dianalisis lebih lanjut dengan teori antrian untuk mendapatkan parameter sistem antrian.

Parameter sistem antrian untuk pelayanan pengambilan nomor (1 loket) untuk pasien yang datang setelah jam 08.00, memiliki parameter antrian sebagai berikut: (1) Tingkat utilitas sistem antrian hanya 18,69\%, sehingga kemungkinan sistem mengalami idle cukup besar yakni mencapai 81,31\%; dan 
(2) Rata-rata panjang antrian pada sistem antrian (L) kurang dari 1 pasien $(0,230$ pasien), dengan rata-rata waktu menunggu dalam sistem adalah 0,006 jam atau sekitar 21 detik per pasien. Kondisi di atas menunjukkan sistem pelayanan berada pada kondisi under utilization.

Sementara itu parameter sistem antrian untuk pelayanan pendaftaran rawat jalan (2 loket) untuk pasien yang datang setelah jam 08.00, memiliki parameter antrian sebagai berikut: (1) Tingkat utilitas sistem antrian hanya 53,33\%, sehingga kemungkinan sistem mengalami idle cukup besar yakni mencapai 46,67\%; dan (2) Rata-rata panjang antrian pada sistem antrian (L) sekitar 2 pasien (1,913 pasien), dengan rata-rata waktu menunggu dalam sistem adalah 0,060 jam atau sekitar 3 menit 36 detik per pasien. Kondisi di atas menunjukkan sistem pelayanan berada pada kondisi under utilization.

\section{Menentukan Sistem Pelayanan yang Optimal}

Analisis trade-off dilakukan terhadap biaya menunggu (dihitung sebagai pendapatan pasien per bulan) dan biaya pelayanan (dihitung sebagai upah minimum per petugas). Hasil perhitungan biaya menunggu dan biaya pelayanan disajikan pada Tabel 5. Sedangkan perhitungan total biaya sistem dihitung dengan formula berikut:

$$
\text { Minimize } E(T C)=E(S C)+E(W C)
$$

$\mathrm{E}(\mathrm{TC})=$ total biaya sistem; $\mathrm{E}(\mathrm{SC})=\mathrm{Cs} \times \mathrm{C}$; dan $\mathrm{E}(\mathrm{WC})=\mathrm{Cw} \times \mathrm{L}$, dimana $\mathrm{Cs}=$ ratarata biaya pelayanan, $\mathrm{Cw}=$ rata-rata biaya menunggu, $\mathrm{L}=$ panjang antrian pada sistem, dan $\mathrm{C}=$ jumlah server/loket.

Berdasarkan Tabel 5, rata-rata pendapatan pasien adalah Rp 1.545.745 (CI 95\%: 1.177 .330 - 1.914.159). Dengan asumsi 1 bulan melayani selama 25 hari, dan jam operasional 1 hari adalah 7 jam, maka rata-rata biaya menunggu per pasien adalah $\mathrm{Rp} 8.832,83$ per jam.

Tabel 5. Distribusi Frekuensi Rata-Rata Pendapatan Pasien Per Bulan (sebagai Rata-Rata Biaya Menunggu)

\begin{tabular}{ccc}
\hline Pendapatan Pasien per Bulan (Rp) & Jumlah & $\%$ \\
\hline$<1.000 .000$ & 50 & 53,1 \\
$1.000 .000-2.000 .000$ & 6 & 6,4 \\
$2.000 .000-3.000 .000$ & 5 & 5,3 \\
$3.000 .000-4.000 .000$ & 28 & 29,8 \\
$4.000 .000-5.000 .000$ & 5 & 5,4 \\
\hline Total & 94 & 100 \\
\hline Mean $=R p$ 1.545.745 per pasien (CI 95\% = 1.177.330-1.914.159); SD $=R p$ 1.798.725; \\
SE $=R p$ 185.524,3; Range = Rp O-5.000.000; Uji Saphiro-Wilk prob $>Z=0,00000$ \\
\hline
\end{tabular}

Berdasarkan data pada Tabel 6 dan dengan asumsi 1 bulan melayani selama 25 hari, dan jam operasional 1 hari adalah 7 jam, maka rata-rata biaya pelayanan untuk: (a) Loket pengambilan nomor $=$ Rp. 40.638,12 dan (b) Loket pendaftaran rawat jalan $=\mathrm{Rp} 20.319,06$.

Tabel 6. Jumlah Petugas Tiap Loket dan Upah Minimum Petugas (sebagai Rata-Rata Biaya Pelayanan)

\begin{tabular}{lcc}
\hline Pelayanan (Loket) & Jumlah & UMK (Rp) \\
\hline Pengambilan nomor antrian & 2 & $7.111 .671,34$ \\
Pendaftaran rawat jalan & & \\
Loket 1 & 1 & $3.555 .835,67$ \\
Loket 2 & 1 & $3.555 .835,67$ \\
Loket 3 & 1 & $3.555 .835,67$ \\
\hline
\end{tabular}


Tabel 7. Analisis Trade-Off Biaya Pelayanan dan Biaya Menunggu

\begin{tabular}{|c|c|c|c|c|c|c|}
\hline $\mathrm{C}$ & $\mathrm{L}$ & Cs & $\mathrm{Cw}$ & $\mathrm{E}(\mathrm{SC})$ & $\mathrm{E}(\mathrm{WC})$ & $\mathrm{E}(\mathrm{TC})$ \\
\hline \multicolumn{7}{|c|}{ Pasien Datang $\leq$ Jam 08.00: Loket Pengambilan Nomor Antrian } \\
\hline 1 & 106.00 & $40,638.12$ & $8,832.83$ & $40,638.12$ & $936,279.98$ & $976,918.10$ \\
\hline 2 & 1.31 & $40,638.12$ & $8,832.83$ & $81,276.24$ & $11,597.51$ & $92,873.75$ \\
\hline 3 & 1.03 & $40,638.12$ & $8,832.83$ & $121,914.36$ & $9,133.15$ & $131,047.51$ \\
\hline 4 & 1.00 & $40,638.12$ & $8,832.83$ & $162,552.48$ & $8,806.33$ & $171,358.81$ \\
\hline 5 & 0.99 & $40,638.12$ & $8,832.83$ & $203,190.60$ & $8,762.17$ & $211,952.77$ \\
\hline \multicolumn{7}{|c|}{ Pasien Datang > 08.00: Loket Pengambilan Nomor Antrian } \\
\hline 5 & 171.48 & $40,638.12$ & $8,832.83$ & $203,190.60$ & $1,514,680.19$ & 1,717 \\
\hline 6 & 7.76 & $40,638.12$ & $8,832.83$ & $243,828.72$ & 68,5 & 312 \\
\hline 7 & 5.75 & $40,638.12$ & $8,832.83$ & $284,466.84$ & $50,762.27$ & 29.11 \\
\hline 8 & 5.24 & $40,638.12$ & $8,832.83$ & $325,104.96$ & $46,266.36$ & $371,371.32$ \\
\hline 9 & 5.07 & $40,638.12$ & $8,832.83$ & $365,743.08$ & 44,7 & 9.03 \\
\hline \multicolumn{7}{|c|}{ Pasien Datang $\leq$ Jam 08.00: Loket Pendaftaran Rawat Jalan } \\
\hline 1 & 0.23 & $20,319.06$ & $8,832.83$ & $20,319.06$ & $2,031.55$ & $22,350.61$ \\
\hline 2 & 0.19 & $20,319.06$ & $8,832.83$ & $40,638.12$ & $1,669.40$ & $42,307.52$ \\
\hline 3 & 0.19 & $20,319.06$ & $8,832.83$ & $60,957.18$ & $1,651.74$ & $62,608.92$ \\
\hline 4 & 0.19 & & 8,83 & 81,2 & & 7.98 \\
\hline 5 & 0.19 & $20,319.06$ & $8,832.83$ & $101,595.30$ & $1,651.74$ & $103,247.04$ \\
\hline \multicolumn{7}{|c|}{ Pasien Datang > 08.00 : Loket Pendaftaran Rawat Jalan } \\
\hline 1 & 16.00 & $20,319.06$ & $8,832.83$ & $20,319.06$ & $141,325.28$ & $161,644.34$ \\
\hline 2 & 1.21 & 20,319.06 & $8,832.83$ & $40,638.12$ & $10,678.89$ & $51,317.01$ \\
\hline 3 & 0.98 & $20,319.06$ & $8,832.83$ & $60,957.18$ & $8,629.67$ & $69,586.85$ \\
\hline 4 & 0.95 & $20,319.06$ & $8,832.83$ & $81,276.24$ & $8,355.86$ & $89,632 \cdot 10$ \\
\hline 5 & 0.94 & $20,319.06$ & $8,832.83$ & $101,595.30$ & $8,320.53$ & $109,915.83$ \\
\hline
\end{tabular}

Hasil analisis trade-off biaya pelayanan dan biaya menunggu menunjukkan sistem pelayanan yang optimal sebagai berikut (Tabel 7):

1. Untuk melayani pasien yang datang sebelum jam 08.00: (1) pada proses pengambilan nomor dilayani 2 loket; dan (2) pada proses pendaftaran rawat jalan dilayani 6 loket.

2. Untuk melayani pasien yang datang setelah jam 08.00: (1) pada proses pengambilan nomor dilayani 1 loket; dan (2) pada proses pendaftaran rawat jalan dilayani 2 loket pelayanan pengambilan nomor antrian.

Parameter sistem antrian yang optimal menunjukkan bahwa seluruh sistem dalam keadaan steady state. Tingkat utilitas sistem tertinggi adalah $82,84 \%$ (pelayanan pendaftaran pasien $\leq$ jam 08.00) dan terendah adalah $9,35 \%$ (pelayanan pendaftaran pasien $>$ jam 08.00).

\section{Pelayanan Pengambilan Nomor untuk Pasien yang Datang Sebelum Jam 08.00}

Berdasarkan analisis trade-off biaya terhadap jumlah pelayanan antara 1-5 loket, jumlah yang optimal adalah sebanyak 2 loket pengambilan nomor antrian. Dengan 2 loket pengambilan nomor, maka biaya pelayanan yang diperoleh adalah yang paling rendah yaitu Rp 85.957 per pasien. Dibanding pelayanan dengan 1 loket (saat ini) yang memiliki biaya pelayanan $\mathrm{Rp} 40.638$ per pasien, biaya pelayanan dengan 2 loket memang lebih besar yaitu Rp 81.276.Namun pada kondisi ini biaya menunggu pasien Rp 11.597 per pasien lebih rendah dibanding dengan loket 1 yaitu $\mathrm{Rp}$ 936.280. Sehingga total biaya hanya Rp 92.873, dibandingkan total biaya saat ini sebesar Rp 976.918.

Berdasarkan analisis sensitivitas, jumlah loket pelayanan pengambilan nomor antrian sebanyak 2 di atas optimal jika tingkat kedatangan $(\lambda)$ bervariasi antara $182-369$ pasien per jam dan tingkat pelayanan $(\mu)$ bervariasi antara 123 - 250 pasien per jam. Artinya jika tingkat kedatangan di luar range tersebut maka jumlah loket tidak optimal, yakni jika kedatangan kurang dari 182 pasien 
per jam maka sebaiknya hanya 1 loket (sistem saat ini), dan jika kedatangan >369 pasien per jam jumlah loket harus ditambah menjadi 3. Pengurangan kedatangan pasien bisa disebabkan oleh beberapa hal seperti adanya perubahan kebijakan dari BPJS, sedangkan peningkatan kedatangan pasien bisa disebabkan penambahan kuota peserta pasien BPJS Kesehatan.

Jika tingkat pelayanan < 123 pasien per jam maka sebaiknya menggunakan 3 loket, sedangkan jika tingkat pelayanan meningkat menjadi > 250 pasien maka sebaiknya 1 loket. Pengurangan tingkat pelayanan bisa terjadi jika adanya perubahan kebijakan pelayanan pasien BPJS Kesehatan yang mengakibatkan bertambahnya proses pelayanan. Sedangkan kenaikan tingkat pelayanan jika adanya penambahan teknologi pendaftaran, misalnya menggunakan mesin pendaftaran otomatis.

Adapun parameter sistem antrian optimal untuk pelayanan pengambilan nomor (2 loket) untuk pasien yang datang sebelum jam 08.00 sebagai berikut: (1) Tingkat utilitas sistem antrian adalah 49,5\%, sehingga kemungkinan sistem mengalami idle adalah 50,4\%; dan (2) Rata-rata panjang antrian pada sistem antrian adalah 1 pasien $(\mathrm{L}=1,313)$, dengan rata-rata waktu menunggu dalam sistem adalah 0,006 jam atau 3,6 menit per pasien.

Berdasarkan parameter tersebut, pelayanan pengambilan nomor lebih "longgar" dibanding konsisi saat ini. Kelonggaran ini dapat dipakai untuk memberikan edukasi tentang rujukan BPJS Kesehatan kepada pasien baik secara paralel (kedua loket sama-sama memberikan edukasi) atau secara serial (ada loket yang khusus memberi edukasi dan loket yang mengurus pemberian nomor antrian).

\section{Pelayanan Pendaftaran Rawat Jalan untuk Pasien yang Datang Sebelum Jam 08.00}

Berdasarkan analisis trade-off biaya terhadap jumlah pelayanan antara 1-5 loket, jumlah yang optimal adalah sebanyak 6 loket pendaftaran rawat jalan. Dengan 6 loket pendaftaran rawat jalan, maka biaya pelayanan yang diperoleh adalah yang paling rendah yaitu Rp 312.345 per pasien (Biaya menunggu Rp 68.516 per pasien dan biaya pelayanan Rp 243.829 per pasien) di antara alternatif jumlah loket yang lainnya. Sistem optimal ini tidak dapat dibandingkan dengan saat ini yang memiliki kondisi tidak steady state.

Berdasarkan analisis sensitivitas, jumlah loket pelayanan pendaftaran rawat jalan sebanyak 6 di atas optimal jika tingkat kedatangan $(\lambda)$ bervariasi antara $151-181$ pasien per jam dan tingkat pelayanan $(\mu)$ bervariasi antara $32-38$ pasien per jam. Jika tingkat kedatangan kurang dari 151 pasien per jam maka sebaiknya hanya 5 loket (sistem saat ini), dan jika kedatangan > 369 pasien per jam jumlah loket harus ditambah menjadi 7 . Jika tingkat pelayanan $<32$ pasien per jam maka sebaiknya menggunakan 7 loket, sedangkan jika tingkat pelayanan meningkat menjadi > 38 pasien maka sebaiknya 5 loket.

Adapun parameter sistem antrian optimal untuk pelayanan pendaftaran rawat jalan (6 loket) untuk pasien yang datang sebelum jam 08.00 sebagai berikut: (1) Tingkat utilitas sistem antrian adalah 82,8\%, sehingga kemungkinan sistem mengalami idle adalah $17,2 \%$; dan (2) Rata-rata panjang antrian pada sistem antrian adalah $7-8$ pasien $(\mathrm{L}=7,757)$, dengan rata-rata waktu menunggu dalam sistem adalah 0,046 jam atau 2 menit 46 detik per pasien.

Dengan kondisi berdasarkan parameter di atas, rata-rata akan terdapat 7-8 pasien yang mengantri di ruang tunggu pendaftaran sehingga bottle neck pendaftaran pasien pada pagi hari bisa dikurangi. Saat ini berdasarkan parameter sistem pengambilan nomor (1 loket), rata-rata pasien yang mengantri 
adalah 106 pasien, sehingga sistem optimal dapat secara menurunkan jumlah antrian secara siginifikan.

Implikasi teknis dari sistem optimum ini ada dua hal yang harus dipertimbangkan yaitu bagaimana menambah loket dan bagaimana mengetahui nomor pasien yang datang sebelum jam 08.00. Untuk jawaban pertama, manajemen rumah sakit dapat membuat loket semi permanen untuk melayani pasien BPJS Kesehatan yang datang sebelum jam 08.00 di sisi kiri ruang tunggu baik untuk loket pengambilan nomor dan loket pendaftaran rawat jalan dengan tenaga yang bersifat tidak permanen. Untuk menjawab masalah kedua, berdasarkan hasil pengamatan nomor antrian kedatangan yang diberikan petugas tepat pada jam 08.00 bervariasi antara nomor 189-231 (rata-rata = 211). Rata-rata nomor kedatangan dapat dijadikan sebagai standar untuk menentukan pengurangan loket yang melayani dari 4 menjadi 2. Secara teknis sebenarnya dapat dilakukan dengan dua cara yaitu: (1) petugas loket pengambilan nomor menginformasikan nomor pasien pada tepat kedatangan jam 08.00; atau jika secara teknis sulit dilakukan maka dapat menggunakan cara kedua (2) yaitu menggunakan standar rata-rata nomor pasien yang diberikan pada jam 08.00. Kondisi ini akan lebih mudah jika rumah sakit mengaplikasikan teknologi pengambilan nomor secara otomatis.

\section{Pelayanan Pengambilan Nomor untuk Pasien yang Datang Setelah Jam 08.00}

Berdasarkan analisis trade-off biaya terhadap jumlah pelayanan antara 1-5 loket (lihat gambar 5 kiri), jumlah yang optimal adalah sebanyak 1 loket pengambilan nomor antrian. Dengan 1 loket pengambilan nomor, maka biaya pelayanan yang diperoleh adalah yang paling rendah dibanding alternatif lainnya yaitu Rp 22.350 per pasien. Kondisi ini tetap mempertahankan sistem pelayanan saat ini atau tidak mengalami perubahan.

Berdasarkan analisis sensitivitas, jumlah loket pelayanan pengambilan nomor antrian sebanyak 1 loket di atas optimal jika tingkat kedatangan $(\lambda)$ kurang dari 163 pasien per jam dan tingkat pelayanan $(\mu)>53$ pasien per jam. Jika kedatangan di atas 163 pasien per jam maka sebaiknya menggunakan 2 loket, dan jika tingkat pelayanan kurang dari 53 pasien per jam harus ditambah menjadi 2 loket. Pengurangan kedatangan pasien bisa disebabkan oleh beberapa hal seperti adanya perubahan kebijakan dari BPJS, sedangkan peningkatan kedatangan pasien bisa disebabkan penambahan kuota peserta pasien BPJS Kesehatan. Di antara kedua hal tersebut, yang memungkinkan adalah terjadinya penambahan peserta menjelang pencapaian target $100 \%$ universal health coverage tahun 2019.

Adapun parameter sistem antrian optimal untuk pelayanan pengambilan nomor (1 loket) untuk pasien yang datang setelah jam 08.00 sebagai berikut: (1) Tingkat utilitas sistem antrian adalah 19,0\%, sehingga kemungkinan sistem mengalami idle adalah 81\%; dan (2) Rata-rata panjang antrian pada sistem antrian adalah sekitar 1 pasien $(\mathrm{L}=0,230)$, dengan rata-rata waktu menunggu dalam sistem adalah 0,006 jam atau 21 detik per pasien. Berdasarkan parameter di atas penggunaan 1 loket pengambilan nomor pada pasien yang datang setelah jam 08.00 sangat longgar dari sisi waktu. Kondisi ini dapat dimanfaatkan petugas untuk membuat laporan pekerjaan saat ini dan mempersiapkan pekerjaan untuk esok harinya. 


\section{Pelayanan Pendaftaran Rawat Jalan untuk Pasien yang Datang Setelah Jam 08.00}

Berdasarkan analisis trade-off biaya terhadap jumlah pelayanan antara 1-5 loket (lihat gambar 5 kanan), jumlah yang optimal adalah sebanyak 2 loket pendaftaran rawat jalan. Dengan 2 loket pendaftaran rawat jalan, maka biaya pelayanan yang diperoleh adalah yang paling rendah yaitu Rp 51.317 per pasien (Biaya pelayanan $\mathrm{Rp} 40.638$ per pasien dan biaya menunggu Rp 10.679 per pasien) di antara alternatif jumlah loket yang lainnya. Jika dibandingkan dengan sistem saat ini (3 loket), sistem usulan memiliki biaya menunggu lebih tinggi, namun dari sisi biaya pelayanan lebih rendah.

Berdasarkan analisis sensitivitas, jumlah loket pelayanan pendaftaran rawat jalan sebanyak 2 di atas optimal jika tingkat kedatangan $(\lambda)$ bervariasi antara 26 - 53 pasien per jam dan tingkat pelayanan $(\mu)$ bervariasi antara 21 - 42 pasien per jam. Jika tingkat kedatangan kurang dari 26 pasien per jam maka sebaiknya hanya 1 loket, dan jika kedatangan > 53 pasien per jam jumlah loket harus ditambah menjadi 3 (sistem saat ini). Jika tingkat pelayanan $<21$ pasien per jam maka sebaiknya menggunakan 3 loket, sedangkan jika tingkat pelayanan meningkat menjadi > 42 pasien maka sebaiknya 1 loket.

Adapun parameter sistem antrian optimal untuk pelayanan pendaftaran rawat jalan (2 loket) untuk pasien yang datang setelah jam 08.00 sebagai berikut: (1) Tingkat utilitas sistem antrian adalah 47,1\%, sehingga kemungkinan sistem mengalami idle adalah 53,9\%; dan (2) Rata-rata panjang antrian pada sistem antrian sekitar 1 pasien $(\mathrm{L}=1,209)$, dengan rata-rata waktu menunggu dalam sistem adalah 0,038 jam atau 2 menit 17 detik.

Dengan kondisi berdasarkan parameter di atas, tingkat kesibukan sistem optimal dengan sistem yang ada tidak begitu berbeda. Sistem yang diusulkan sangat longgar (tingkat utilitas hanya $47,1 \%$ ), adapun sistem yang ada saat ini memiliki utilitas $31,37 \%$ artinya sistem memiliki porsi waktu 68,63\%. Meskipun secara trade-off sistem usulan memiliki total biaya rendah, namun bila dilihat dari parameter sistem tidak menunjukkan perubahan yang signifikan, sehingga manajemen rumah sakit dapat mempertimbangkan kembali untuk mengganti sistem pelayanan.

Implikasi teknis jika sistem optimal/usulan diterapkan adalah kapan menentukan terjadinya pengurangan loket untuk melayani pasien yang datang pada setelah jam 08.00 dan mengalokasikan tugas/pekerjaan kepada loket yang tidak beroperasi pada waktu yang ditentukan. Untuk menjawab masalah pertama, peneliti mengusulkan menggunakan teknik sebagaimana dijelaskan pada penjelasan di sub bab di atas. Sedangkan untuk alokasi pekerjaan pada loket yang tidak beroperasi disarankan untuk mengerjakan tugas-tugas administratif atau lainnya di luar pelayanan pendaftaran, khususnya untuk loket 3 supervisor. Penggunaan teknologi informasi juga dapat mengurangi waktu tunggu pasien. Sebagaimana studi perbedaan waktu tunggu pasien rawat jalan di sebuah rumah sakit di Korea sebelum dan sesudah penerapan Electronic Medical Record menunjukkan penurunan waktu tunggu yang siginifikan antara 44-78\% (Cho et al., 2017).

Kondisi utilitas antrian pada penelitian ini agak berbeda kondisinya dengan utilitas dokter di ruang emerjensi. Hasil penelitian di China menunjukkan tingkat utilitas yang tidak begitu berbeda antar layanan. Bagi pasien dewasa yang tidak mengalami trauma dan anak-anak tingkat utilitasnya sama yaitu $75 \%$, sedangkan pasien dewasa yang mengalami trauma tingkat utilitas mencapai 53\% (Chung-Hsien et al., 2018). Hasil penelitian pelayanan ambulans di rumah sakit menunjukkan utilitas hanya 9,17\% dengan probalitas tidak adanya pelanggan adalah $75 \%$ (Sisdiyantoro, 2014). 


\section{Persepsi Pasien terhadap Pelayanan}

Untuk mengetahui persepsi pasien terhadap pelayanan pendaftaran di RSU Kabupaten Tangerang sebanyak 94 responden berhasil diwawancarai, dengan profil sebagian besar perempuan, berusia $>40$ tahun dan tidak bekerja. Persepsi pasien terbagi menjadi dua yaitu harapan dan kepuasan terhadap pelayanan dalam dimensi yang berbeda. Sebagian besar pasien (67\%) mengharapkan mendapat nomor antrian sesuai jam pelayanan, kapasitas ruang tunggu dibatasi $(58,5 \%)$, jumlah kursi tunggu dipertahankan $(53,2 \%)$, dan urutan pelayanan dengan first-come first served $(56,4 \%)$. Harapan terhadap pelayanan dijelaskan pada Tabel 8.

Tabel 8. Harapan Responden terhadap Pelayanan Pendaftaran

Pasien BPJS Kesehatan

\begin{tabular}{lcc}
\hline \multicolumn{1}{c}{ Harapan Pasien } & $\mathrm{n}$ & $\%$ \\
\hline Harapan terhadap pengambilan nomor antrian & & \\
Mendapat nomor antrian dini hari (sebelum jam 07.00) & 22 & 23,4 \\
Mendapat nomor antrian sesuai jam pelayanan & 63 & 67,0 \\
Mendapat nomor antrian melalui aplikasi social media & 9 & 9,6 \\
Harapan terhadap kapasitas ruang tunggu & 55 & 58,5 \\
Dibatasi & 39 & 41,5 \\
Tidak perlu dibatas & & \\
Harapan terhadap jumlah kursi tunggu & 50 & 53,2 \\
Dipertahankan & 6 & 6,4 \\
Ditambah & 38 & 40,4 \\
Dikurangi & & \\
Harapan terhadap urutan pelayanan & 53 & 56,4 \\
Mendahulukan yang lebih awal (FCFS) & 41 & 43,6 \\
Memprioritaskan golongan rentan & & \\
\hline
\end{tabular}

Sementara itu, tingkat kepuasan pasien terhadap pelayanan pendaftaran menunjukkan $77,7 \%$ responden menyatakan puas. Hasil uji bivariat menunjukkan tidak ada hubungan antara waktu tunggu dengan kepuasan pasien (p-value $=0,433)$. Hal ini menunjukkan meskipun pasien harus menunggu lama untuk dilayani, namun lamanya waktu tunggu ini tidak berhubungan secara statistik dengan kepuasan pelayanan. Hasil survey menunjukkan 30\% responden kurang puas dengan kecepatan pelayanan (Tabel 9).

Tabel 9. Hubungan antara Kepuasan dengan Waktu Tunggu

\begin{tabular}{|c|c|c|c|c|c|c|c|}
\hline \multirow{3}{*}{ Waktu Tunggu } & \multicolumn{4}{|c|}{ Kepuasan Pasien } & \multirow{2}{*}{\multicolumn{2}{|c|}{ Total }} & \multirow{3}{*}{$\mathrm{p}$-value } \\
\hline & \multicolumn{2}{|c|}{ Puas } & \multicolumn{2}{|c|}{$\begin{array}{c}\text { Kurang } \\
\text { Puas }\end{array}$} & & & \\
\hline & $\mathrm{n}$ & $\%$ & $\mathrm{n}$ & $\%$ & $\mathrm{n}$ & $\%$ & \\
\hline Lebih dari 60 menit & 61 & 76,3 & 19 & 23,7 & 80 & 100,0 & \\
\hline Kurang dari sama dengan 60 menit & 12 & 85,7 & 2 & 14,3 & 14 & 100,0 & 0,433 \\
\hline
\end{tabular}

\section{Simulasi Usulan Sistem Pelayanan}

Hasil simulasi dengan menggunakan analisis sensitivitas terhadap perubahan tingkat kedatangan dan tingkat pelayanan pasien adalah sebagai berikut (Tabel 10 dan Tabel 11):

1. Dengan asumsi tingkat pelayanan tetap maka:

a. Untuk pelayanan pengambilan nomor, usulan sistem berlaku jika tingkat kedatangan pada kisaran 182-369 pasien per jam (untuk pasien datang $\leq$ 
jam 08.00) dan kisaran 1-163 pasien per jam (untuk pasien datang $>$ jam 08.00);

b. Untuk pelayanan pendaftaran rawat jalan, usulan sistem berlaku jika tingkat kedatangan pada kisaran 151-181 pasien per jam (untuk pasien datang $\leq$ jam 08.00) dan kisaran 26-53 pasien per jam (untuk pasien datang > jam 08.00).

2. Dengan asumsi tingkat kedatangan tetap maka:

a. Untuk pelayanan pengambilan nomor, usulan sistem berlaku jika tingkat pelayanan pada kisaran 123-250 pasien per jam (untuk pasien datang $\leq$ jam 08.00) dan kisaran 1-52 pasien per jam (untuk pasien datang $>$ jam 08.00);

b. Untuk pelayanan pendaftaran rawat jalan, usulan sistem berlaku jika tingkat pelayanan pada kisaran 32-38 pasien per jam (untuk pasien datang $\leq$ jam 08.00) dan kisaran 21-42 pasien per jam (untuk pasien datang $>$ jam 08.00).

Tabel 10. Analisa Sensitivitas Usulan Sistem Pelayanan berdasarkan Perubahan pada Tingkat Kedatangan $(\lambda)$

\begin{tabular}{|c|c|c|c|c|c|}
\hline \multirow{2}{*}{ No } & \multirow{2}{*}{ Usulan Sistem } & \multirow{2}{*}{$\mu$} & \multirow{2}{*}{$\lambda$} & \multicolumn{2}{|c|}{ Range $\lambda$} \\
\hline & & & & Minimum & Maximum \\
\hline \multirow[t]{3}{*}{1} & Pengambilan Nomor & & & & \\
\hline & Pasien $\leq$ Jam $08.00(c=2)$ & 214 & 212 & $\begin{aligned}< & 182 \text { pasien } / \text { jam } \\
& (\text { sebaiknya } \mathrm{c}=1 \text { ) }\end{aligned}$ & $\begin{array}{c}>369 \text { pasien } / \mathrm{jam} \\
(\text { sebaiknya } \mathrm{c}=3 \text { ) }\end{array}$ \\
\hline & Pasien $>$ Jam $08.00(c=1)$ & 214 & 40 & - & $\begin{array}{l}>163 \text { pasien } / \mathrm{jam} \\
(\text { Sebaiknya } \mathrm{c}=2)\end{array}$ \\
\hline \multirow[t]{3}{*}{2} & Pendaftaran Rawat Jalan & & & & \\
\hline & Pasien $\leq$ Jam $08.00(c=6)$ & 34 & 169 & $\begin{array}{l}<151 \text { pasien } / \text { jam } \\
(\text { Sebaiknya } \mathrm{c}=5)\end{array}$ & $\begin{array}{l}>18 \text { pasien } / \mathrm{jam} \\
(\text { Sebaiknya } \mathrm{c}=7)\end{array}$ \\
\hline & Pasien $>$ Jam $08.00(c=2)$ & 34 & 32 & $\begin{array}{c}<26 \\
(\text { Sebaiknya c }=1)\end{array}$ & $\begin{array}{c}>53 \\
(\text { Sebaiknya c }=3)\end{array}$ \\
\hline
\end{tabular}

Tabel 11. Analisa Sensitivitas Usulan Sistem Pelayanan berdasarkan Perubahan pada Tingkat Pelayanan $(\mu)$

\begin{tabular}{|c|c|c|c|c|c|}
\hline \multirow{2}{*}{ No } & \multirow{2}{*}{ Usulan Sistem } & \multirow{2}{*}{$\mu$} & \multirow{2}{*}{$\lambda$} & \multicolumn{2}{|c|}{ Range $\mu$} \\
\hline & & & & Minimum & Maximum \\
\hline \multirow[t]{3}{*}{1} & Pengambilan Nomor & & & & \\
\hline & Pasien $\leq$ Jam $08.00(c=2)$ & 214 & 212 & $\begin{array}{c}<123 \text { pasien } / \mathrm{jam} \\
(\text { sebaiknya } \mathrm{c}=3)\end{array}$ & $\begin{array}{c}>250 \text { pasien } / \text { jam } \\
(\text { sebaiknya } \mathrm{c}=1)\end{array}$ \\
\hline & Pasien $>$ Jam $08.00(c=1)$ & 214 & 40 & $\begin{array}{l}<53 \text { pasien } / \text { jam } \\
(\text { sebaiknya } \mathrm{c}=2 \text { ) }\end{array}$ & - \\
\hline \multirow[t]{3}{*}{2} & Pendaftaran Rawat Jalan & & & & \\
\hline & Pasien $\leq$ Jam $08.00(c=6)$ & 34 & 169 & $\begin{array}{l}<32 \text { pasien } / \text { jam } \\
(\text { Sebaiknya } \mathrm{c}=7 \text { ) }\end{array}$ & $\begin{array}{l}>38 \text { pasien } / \text { jam } \\
(\text { Sebaiknya } \mathrm{c}=5)\end{array}$ \\
\hline & Pasien $>$ Jam $08.00(c=2)$ & 34 & 32 & $\begin{array}{c}<21 \\
(\text { Sebaiknya } \mathrm{c}=3)\end{array}$ & $\begin{array}{c}>42 \\
(\text { Sebaiknya } \mathrm{c}=1)\end{array}$ \\
\hline
\end{tabular}

\section{Kajian Terhadap Pengelolaan Antrian}

Pada dasarnya pengelolaan antrian pasien bukan hanya mempertimbangkan aspek teknis dan finansial saja, melainkan memperhatikan aspek pengalaman pasien dalam mengantri. Hal ini sebagaimana yang dinyatakan oleh (Weiss \& Tucker, 2018) yang mengusulkan pengelolaan antrian didasarkan pada aspek sistem (waktu) dan psikologis, yaitu (1) mengurangi atau menghilangkan kejadian menunggu; (2) mengelola harapan pasien; dan (3) meningkatkan kualitas pengalaman pasien saat menunggu. 
Hasil survey terhadap kepuasan pasien menunjukkan $77 \%$ pasien menyatakan puas terhadap pelayanan pendaftaran di instalasi rawat jalan RSU Kabupaten Tangerang. Namun demikian untuk atribut kecepatan pelayanan ada $30 \%$ pasien yang menyatakan tidak puas, merupakan atribut dengan tingkat ketidakpuasan tertinggi dibanding atribut lainnya. Hasil uji korelasi menunjukkan tidak ada hubungan secara statistik antara kepuasan pasien dengan karakteristik personal, perilaku mengantri, urutan pelayanan, dan waktu tunggu. Dengan demikian, ada kemungkinan keputusan menambah atau mengurangi jumlah loket belum tentu mempengaruhi kepuasan pasien. Hasil ini berbeda dengan studi yang dilakukan di sebuah apotik di Manado yang menunjukkan ada hubungan antara waktu tunggu pelayanan resep dengan kepuasan pasien (Nurjanah dkk, 2016).

Antrian panjang pasien terjadi ketika pelayanan kesehatan bekerja secara tidak efisien dan memicu ketidakpuasan. Pada pelayanan radiologi diusulkan empat langkah dalam mengelola antrian yaitu menganalisis faktor yang mempengaruhi terbentuknya antrian, meningkatkan proses untuk mengurangi waktu pelayanan, mengurangi variabilitas, dan menerapkan konsep psikologi antrian (Loving et al., 2017).

Usulan penambahan/pengurangan loket pelayanan di atas bukan hanya upaya untuk mengurangi waktu tunggu pasien namun juga memperhatikan biaya yang dikeluarkan baik oleh rumah sakit maupun oleh pasien. Usulan sistem tersebut jika dibandingkan dengan sistem pelayanan yang ada memiliki biaya total yang lebih rendah, meskipun terjadi penambahan loket. Perbedaan biaya sangat besar pada pelayanan untuk pasien yang datang $\leq$ jam 08.00, dimana biaya yang diusulkan adalah Rp 196.382,22 per jam dibandingkan biaya sistem saat ini sebesar lebih dari Rp 1.120.896,61. Sementara untuk pelayanan kedatangan pasien > jam 08.00 selisih lebih sedikit. Sistem saat ini berbiaya Rp 108.396,58, sedangkan yang diusulkan berbiaya Rp 91.963,96. Dapat ditarik kesimpulan sebagai berikut:

1. Usulan pada penambahan loket untuk pasien yang datang sebelum jam 08.00 lebih ditujukan untuk mengurangi biaya menunggu pasien. Keputusan menambah petugas sesuai dengan sistem yang diusulkan akan menurunkan antrian pasien dan menurunkan biaya yang harus dikeluarkan pasien akibat menunggu, meskipun rumah sakit harus menambah investasi untuk menjalankan alternatif sistem ini.

2. Usulan pada pengurangan loket untuk melayani pasien yang datang $>$ jam 08.00 ditujukan untuk mengurangi biaya pelayanan. Pengurangan biaya pelayanan ini dapat dijadikan sebagai pengurangan beban menambah petugas pada pelayanan pasien di bawah jam 08.00. Namun demikian, perbedaan biaya menunggu yang timbul tidak terlalu signifikan. Artinya manajemen rumah sakit dapat mempertimbangkan untuk tidak menjalankan opsi tersebut.

Studi antrian pada pelayanan emerjensi di Mexico menunjukkan keputusan menetapkan jumlah dokter pada tingkat yang minimal menyebabkan kepadatan pasien makin bertambah dan panjangnya waktu pelayanan terutama pada pasien dengan prioritas rendah. Namun keputusan menambah dokter tetap untuk melakukan pelayanan juga tidak layak. Peneliti menyarankan pengendalian pada permintaan pelayanan untuk menentukan alokasi dokter yang efisien (Jauregui et al., 2017). Begitu pula studi pelayanan farmasi rumah sakit di Iran menunjukkan sistem antrian yang efisien dapat dicapai dengan menempatkan petugas yang multi-tasking atau yang tidak menetap pada satu proses saja (Bahadori et al., 2014). 


\section{PENUTUP}

Berdasarkan hasil penelitian dapat disimpulkan karakteristik tingkat kedatangan dan tingkat pelayanan pasien di sistem antrian pendaftaran pasien BPJS Kesehatan menunjukkan hal yang umum terjadi pada pelayanan kesehatan lainnya yaitu berdistribusi Poisson. Berdasarkan analisis parameter antrian sistem saat ini berdasarkan teori antrian, pelayanan pada pasien yang datang sebelum jam 08.00 sangat sibuk, bahkan pada proses pendaftaran daftar rawat jalan menunjukkan kondisi tidak steady state karena tingkat kedatangan pasien lebih besar dibanding tingkat pelayanan. Sedangkan pelayanan pasien yang datang setelah jam 08.00 menunjukkan kondisi yang terkendali (tidak sibuk) dan pada proses pendaftaran rawat jalan sudah menunjukkan kondisi steady state. Namun berdasarkan analisis trade-off, menunjukkan bahwa sistem pelayananan yang ada saat ini tidak optimum ditinjau dari biaya menunggu dan biaya pelayanan yang ditimbulkan. Sistem yang diusulkan untuk melayani pasien yang datang sebelum jam 08.00 adalah menambah loket pengambilan nomor antrian menjadi 2 (sebelumnya 1), dan menambah jumlah loket pendaftaran rawat jalan menjadi 6 (sebelumnya 5). Sedangkan pada pelayanan terhadap pasien yang datang setelah jam 08.00, untuk proses pengambilan nomor antrian tidak ada perubahan, dan pada proses pendaftaran rawat jalan terjadi pengurangan menjadi 2 loket. Berdasarkan analisis menggunakan teori antrian, sistem yang diusulkan mampu menurunkan panjang antrian pasien secara signifikan terutama pada pasien yang datang sebelum jam 08.00. Perubahan panjang antrian pada pelayanan pasien yang datang di atas jam 08.00 tidak begitu signifikan. Berdasarkan survey terhadap persepsi pelayanan, menunjukkan $30 \%$ responden menyatakan tidak puas terhadap kecepatan pelayanan di pendaftaran rawat jalan. Secara keseluruhan pasien menyatakan puas $(77 \%)$ terhadap seluruh atribut pelayanan di bagian pendaftaran rawat jalan. Hasil analisis korelasi menunjukkan tidak ada hubungan antara kepuasan pasien dengan waktu tunggu, meskipun rata-rata pasien harus menunggu 108,6 menit sejak datang hingga dilayani oleh bagian pendaftaran. Hal ini berarti ada faktor lain yang lebih berpengaruh di luar waktu tunggu. Manajemen rumah sakit diharapkan lebih memfokuskan pelayanan pada pasien BPJS Kesehatan yang datang sebelum jam 08.00 untuk menghindari terjadinya kondisi yang tidak terkendali. Untuk mengurangi antrian disarankan menambah loket yang bersifat tidak permanen (dilihat dari jam operasional dan lokasi) baik saat pengambilan nomor maupun saat pendaftaran rawat jalan. Jika sistem telah selesai melayani pasien yang datang sebelum jam 08.00, maka jumlah loket dapat kurangi pada kedua proses. Manajemen rumah sakit dalam menerapkan sistem yang diusulkan agar mempertimbangkan alokasi waktu, karena sistem yang diusulkan tidak seluruhnya memiliki utilisasi $100 \%$ terutama untuk melayani pasien yang datang di atas jam 08.00. Mempertahankan atribut pelayanan yang ada saat ini (keramahan, kesigapan petugas, kenyamanan ruangan, dan sebagainya) karena kondisi ini kemungkinan yang menyebabkan pasien tetap puas meskipun harus menunggu lama. Bila memungkinkan, manajemen rumah sakit mulai mengaplikasikan mesin otomatis pengambilan nomor antrian untuk membantu loket pendaftaran dalam memonitor nomor pasien yang datang sebelum jam 08.00

\section{UCAPAN TERIMA KASIH}

Penelitian ini dibiayai oleh Kementerian Riset dan Teknologi RI melalui hibah Penelitian Dosen Pemula. Ucapan terima kasih ditujukan kepada pimpinan dan staff RSU Kabupaten Tangerang serta LPPM Universitas Esa Unggul yang membantu memfasilitasi penelitian ini. 


\section{DAFTAR PUSTAKA}

Bahadori MK, Mohammadnejhad SM, Ravangard R, Teymourzadeh E. 2014. Using Queuing Theory and Simulation Model to Optimize Hospital Pharmacy Performance. Iran Red Crescent Med J. Vol 16 (3): 1 - 21.

Cho KW, Kim SM, Chae YM, Song YU. 2017. Application of Queueing Theory to the Analysis of Changes in Outpatient's Waiting Times in Hospitals Introducing EMR. Healthcare Informatics Research. 23(1): 35-42.

Chung-Hsien C, Hsiu-Hsi C, Tang P, Ming-Fang Yen A, Kuan-han W, Cheng-Ting $\mathrm{S}$, Te-Fa C. 2018. Traffic Intensity of Patients and Physicians in the Emergency Department: A Queueing Approach for Physician Utilization. The Journal of Emergency Medicine. 55(5): 718-725.

Fuanasari AD, Suparwati A, Wigati PA. 2014. Analisis Alur Pelayanan Dan Antrian Di Loket Pendaftaran Pasien Rawat Jalan. Jurnal Kesehatan Masyarakat (e-Journal). 2(1): 15-21.

Gupta D. 2013. Queueing Models for Healthcare Operations. In B. T. Denton (Ed.), Handbook of Healthcare Operation Management: Methods and Applications. pp. 19-44). New York: Springer Science+Business.

Hollensen S. 2010. Marketing Management: A Relationship Approach (2nd ed.). London: Pearson Education.

Hillier FS \& Lieberman GJ. 2015. Introduction to Operation Research (10th ed.). New York: McGraw-Hill.

Heryana A. 2001. Menentukan Jumlah Petugas Pelayanan Resep yang Optimal di Apotik Damayanti \& Associates dalam Rangka Peningkatan Mutu Pelayanan. Politeknik STMI Jakarta.

Jauregui GRR, Perez AKG, Gonzalez SH, Ripalda MDH. 2017. Analysis of the Emergency Service Applying the Queueing Theory. Contaduria $y$ Administracion. 62(3): 733-745.

Lisdawati S, Setyaningsih S, Andriyati A. 2015. Penerapan Sistem Antrian pada Pelayanan Pasien Badan Penyelenggara Jaminan Sosial (BPJS) Rumah Sakit (Studi Kasus: Rumah Sakit Dr. H. Marzoeki Mahdi Bogor). Retrieved June 7, 2017, from http://perpustakaan.fmipa.unpak.ac.id/file/e-jurnal suci 064112021.pdf

Loving VA, Ellis RL, Rippee R, Steele JR, Schomer DF, Shoemaker S. 2017. Time is not on Our Side: How Radioogy Practices should Manage Customer Queues. Journal of American College of Radiology. 14(11): 1481-1488.

Nurjanah I, Maramis FR, Engkeng S. 2016. Hubungan Antara Waktu Tunggu Pelayanan Resep dengan Kepuasan Pasien di Apotek Pelengkap Kimia Farma BLU Prof. Dr. RD Kandou Manado. Jurnal Ilmiah Farmasi UNSTRAT. 5(1): 362-370.

Prabhu NU. 1997. Foundation of Queueing Theory. New York: Science+Business, Springer.

Purwanto H, Indiati I, Hidayat T. 2015. Faktor Penyebab Waktu Tunggu Lama di Pelayanan Farmasi Rawat Jalan RSUD Blambangan. Jurnal Kedokteran Brawijaya. 28(2): 159-162.

Septiani AS, Wigati PA, Fatmasari EY. 2017. Gambaran Sistem Antrian Pasien dalam Optimasi Pelayanan di Loket Pendaftaran Instalasi Rawat Jalan Rumah Sakit Umum Pusat Fatmawati. Jurnal Kesehatan Masyarakat (eJournal). 5(4): 1-14.

Sisdiyantoro K. 2014. Analisis Antrian Pelayanan Instalasi Ambulance pada Rumah Sakit Umum Daerah Dr. Iskak Tulung Agung. Benevit. 1(1): 103120.

Van Brummelen SP, De Kort W, Van Dijk NM. 2018. Queue Length Computation of Time-dependent Queueing Networks and its Application to Blood Collection. Operation Research for Health Care. 17. 4-15. Retrieved from 
https://www.sciencedirect.com/science/article/abs/pii/S22116923163012 17

Weiss EN, Tucker C. 2018. Queue Management: Elimination, Expectation, and Enhancement. Business Horizons. 61(5): 671-678.

Wihdaniah S, Pono M, Munizu M. 2018. Analisis Kinerja Sistem Antrian dalam Mengoptimalkan Pelayanan Pasien Rawat Jalan di RSUD Haji Makassar. Bisnis, Manajemen, Dan Informatika. 14(3): 228-238. 